\title{
Editorial*
}

\section{TALKing about European Democracy}

The New York Times called 2017, the year in which the European Union celebrates 60 years since the signature of the Treaties of Rome, 'Europe's year of political reckoning. ${ }^{1}$ Media attention to national elections in EU member states is more intense than ever before ${ }^{2}$ and Europe and beyond look at them with greater curiosity and concern than has been the case in recent decades. How would Wilders do in the Netherlands in March, Le Pen in France in April at the presidential election and in June at parliamentary elections, the xenophobic Alternative für Deutschland in Germany in September, the anti-political, anti-immigrant and anti-Euro 'five star movement' Cinque stelle in Italy in the autumn? And what will come of the movement of dissatisfied citizens ANO 2011 and its own version of antiestablishment politics run by one of the wealthiest men in the Czech Republic?

The urgency with which trends in various smaller and larger European states are being watched mixes with an unease over democracy in the Union and the democratic nature of the Union. Democracy has been the greatest challenge for

*The text of this editorial comment was finalised on 18 April 2017.

${ }^{1}$ NY Times, 13 March 2017, <www.nytimes.com/2017/03/13/world/europe/netherlands-electionmuslims.html?emc=edit_nn_20170313\&nl=morning-briefing\&nlid=77515315\&te=1\&_r=0>, visited 20 April 2017.

${ }^{2}$ Media attention to each other's national elections is more intense than ever before, to the point of both tabloids and serious media rapidly copying half understood and outright fake news. A Reuter's correspondent posted a message on an allegedly unanimous resolution in the Dutch Parliament to hold an investigation into the Euro; the Daily Telegraph's Europe correspondent turned this into a resolution to hold a 'parliamentary enquiry', <www.telegraph.co.uk/news/ 2017/02/25/netherlands-holds-inquiry-whether-could-ditch-euro/>; The Sun turned it into a Wilders inspired 'full parliamentary enquiry', <www.thesun.co.uk/news/2952587/dutch-vote-overeuro-axe/>; the Frankfurter Allgemeine thought there was an unanimous parliamentary vote asking to consider the options for the Netherlands to leave the Euro. In fact, a resolution, supported by Wilders, to hold a parliamentary enquiry was rejected. The resolution that was passed with contrary votes of Wilders and the anti-European parties, asked for an advisory opinion of the Netherlands Council of State primarily on improved enforcement of the rules governing the Euro, the last thing Wilders would want, see <zoek.officielebekendmakingen.nl/dossier/34387/h-tk-20162017-49-15? resultIndex $=0 \&$ sorttype $=1 \&$ sortorder $=4>$, visited 20 April 2017 . 
Europe, not only for the Union's institutional make-up, but also for and in the states that are members of it. Political movements and parties, no longer only those branded as 'populist', contest the democratic credentials of established institutions. Some of them, on coming to power, erode them. A programme of dismantling democracy was rolled out in Hungary before it was noticed in Brussels and other European capitals, and in Poland we see exactly the same. The scenarios are ready and tested for others to follow.

This calls for reflection: it is time to talk about European democracy. Our starting point is the entwinement of the Union's and the Member States' constitutional and political orders. We next make several series of remarks on democracy itself, before embarking on the Union's state of democracy and that of the Member States.

\section{Constitutional Entwinement - Political Entwinement}

The Union has been based predominantly on the paradigm of 'integration through law', and its normative foundations have largely been articulated in terms of the 'rule of law'. This has not only pushed the normative justifications for the economic paradigms pursued by the Union into the background, but also has done this to the normative justifications on which the Union is based politically. Rather than a rule of law that is merely viewed as a 'prerequisite for the proper functioning of the internal market', and of the 'mutual trust' that is needed for 'an investment and business friendly environment', ${ }^{3}$ it is democracy that merits our attention.

The Maastricht Treaty's ambition of establishing the EU as a political union was expressed in its preamble and accompanied with the provision that ' $\mathrm{t}$ ]he Union shall respect the national identities of its Member States, whose systems of government are founded on the principles of democracy. ${ }^{4}$ This provision seems to make the respect of national identity conditional on the democratic nature of the Member States. The Amsterdam Treaty amended this provision so as to separate out the Union's duty to respect the national identity of Member States from the legal principle that ' $[\mathrm{t}]$ he Union is founded on the principles of liberty, democracy, respect for human rights and fundamental freedoms, and the rule of law, principles which are common to the Member States. ${ }^{5}$ This is basically retained in

\footnotetext{
${ }^{3}$ Vice-President Timmermans, LIBE Committee meeting 21 March 2017, On the Rule of Law in Poland: state of play <www.europarl.europa.eu/ep-live/en/committees/video?event $=20170322$ 1500-COMMITTEE-LIBE > at 9 minutes, 17 seconds and 58 minutes, 8 seconds. In nearly identical terms, repeating the argument as to the importance of judicial independence for the functioning of the internal market three times over, in the EP plenary debate of 14 December 2016, $<w w w . e u r o p a r l . e u r o p a . e u / e p-l i v e / e n /$ plenary/video?debate $=1481728381101>$, at 16:18':01”.

${ }^{4}$ Art. F(1) TEU (Maastricht).

${ }^{5}$ Art. 6(1) TEU (Amsterdam); the duty to respect the national identities of Member States was contained in Art. 6(3) TEU (Amsterdam).
} 
Article 2 TEU in its present version, where these principles are dubbed 'values'. Note how, according to this provision, the value of democracy is the foundation of the Union and simultaneously common to the Member States. So the foundation of the Union is not the internal market, not the economic freedoms, nor undistorted competition and a level playing field for companies. The foundational entwinement of Union and Member States is not an economic one based on the internal market logic, but is a political one: it expresses the mutual intertwining of the political orders of Member States within and with the Union, political orders that are and that must be democratic political orders.

The constitutional surface story of how Union and Member States are inextricably linked is so well-known as to become tedious. But it is not therefore less important as a starting-point. The EU institutions have a democratic counterpart in the Member States that in various manifestations are an integral component of its political decision-making. This is articulated in Article $10 \mathrm{TEU}$, where the role of the Heads of State or Government in the European Council, as well as that of government representatives in the Council, is acknowledged as being legitimated under the national democratic constitutional arrangements; ${ }^{6}$ similarly, the role of national parliaments as contributing to the democratic life of the Union is spelt out in Article 12 TEU. Thus, the constitutional design reveals an intense involvement of national democratic institutions with the Union, as well as influence of the citizens themselves. ${ }^{7}$ Indeed, the democracy of the Union and the democracy of the Member States are constitutionally intertwined. The media attention we signalled above suggests, however, that this is so not merely in terms of institutional design but also in terms of actual political fact.

The public salience of this year's elections in Europe results to a large degree from the transnational effect of electoral outcomes. The development of the EU is understood to be affected by, or even to depend on the outcome of national elections. Clearly, a victory for Marine Le Pen would be a test for the Union, as she has announced a referendum on continued membership to be held immediately if she wins the presidential election. The French remain divided as to their attachment to the EU, with 65\% of respondents in the autumn 2016 Eurobarometer tending not to have confidence ('plutôt pas confiance') in the EU (though $79 \%$ and $74 \%$ tending not to have confidence in the national government and parliament); yet only $31 \%$ of respondents were found to believe that France would face a better future outside the EU. ${ }^{8}$ So both the elections and a possible subsequent EU referendum might be a close call. Already in advance

\footnotetext{
${ }^{6}$ Art. 10(2), second sentence TEU.

${ }^{7}$ Art. 10(2) first sentence, 10(3) and 11 TEU.

${ }^{8}<$ ec.europa.eu/COMMFrontOffice/publicopinion/index.cfm/Survey/getSurveyDetail/instruments/ STANDARD/surveyKy/2137>, visited 20 March 2017.
} 
Le Pen has cleverly turned her Frexit-referendum into a referendum on her own political future. ${ }^{9}$ Perhaps this is not surprising, yet it is quite new: present and future presidents and prime ministers putting their political future at stake on the basis of their country's future within Europe.

Clearly, even when the existence of the EU or membership of it turns out not to be at stake, national elections will influence the further development of the Union: the Brexit negotiations, trade policies, economic policies, migration policies, the relations with Russia, Turkey and the US, to mention only a few. Democratic choices at national level have potentially and actually great influence on Union policies.

There is another aspect to this political entwinement. The Union is not merely democratic because of the outcome of democratic elections on which politics in the institutions are based. The institutions themselves have to live up to democratic principles of accountability and openness - something that has taken a long time to evolve. Moreover, we must not forget that the Union is also conceived as a consolidator of democracy in the Member States from its very inception. So democracy is certainly not a one-way street, but a reciprocal premise of living in political society in Europe. This should have consequences in the face of vociferous claims to the contrary being heard these days, all in the name of democracy.

\section{Democracy: Representative Claims}

The 'political reckoning' the New York Times talked of was above all about democratic challenges posed by the rise of anti-immigration, anti-Islam and anti-establishment sentiments in politics; and anti-EU sentiment certainly forms part of anti-establishment sentiment. These are sentiments that are far from pertaining only to extremist fringe groups like Jobbik, or not-so-fringe parties like Wilders or the Front National. Some of the 'populist' language that had previously been taboo, perhaps for fear of losing votes, has entered into the vocabulary of well-established parties like those of Christian democrat and labour orientation, as well as liberal parties. Instead of viewing European integration as a progressive movement against the established sovereign state system that caused havoc and brought ruin to Europe, anti-EU sentiment as anti-establishment sentiment seems to be based on a nostalgia for an unspecified past, witness slogans about making this or that country great 'again'. This is often accompanied by appeals to sovereignty and mixed up with anti-solidarity, anti-cooperation and anti-social versions of 'us first'. We even hear claims by politicians that the numerical

\footnotetext{
${ }^{9}$ Soundclip from an interview with Peter Vermaas, March 2017, <static.nrc.nl/2017/lepen/ marine.mp3>, visited 20 March 2017. She has also indicated she will first renegotiate France's territorial, monetary, economic and legislative sovereignty, and at any rate return to the monetary system from before Maastricht.
} 
minority they actually represent are the 'real people', as opposed to the others. As a sequel, claims are made that parliament is a 'fake parliament' because it insufficiently represents that 'real people' (Wilders).

'We are the people' was the slogan from Leipzig that spread through the DDR to make the Berlin Wall come tumbling down in the autumn of 1989. From that constitutional moment, present-day Europe arose. In the political rhetoric of today, representative claims to the 'real people' are made that seem like distant echoes hoping for a new constitutional moment.

In assessing this representational claim we need to be precise about a few essentials of political democracy, essentials that may seem to state the obvious, but merit consideration under the political circumstances in which Europe finds itself.

Traditionally, representational claims are channelled through constitutional arrangements into political institutions. The French Revolution and in particular its claim of 'sovereignty of the people' has left strong traces in continental European constitutional conceptions of democracy. The Bundesverfassungsgericht's notion of Kettenlegitimation ('chain legitimacy'), ${ }^{10}$ so central to its Maastricht-, Lissabon- and some of its Eurokrise-judgments, is a relevant and prominent expression of this. The idea is that any exercise of public authority should lead back in an unbroken chain to the expression of the sovereign will of the people in elections: from the enforcement of an executive decision to a legislative act to the election of the legislative power; from the police to the executive to parliament to the people. This is what, in the less specific terminology of systems theory, is known as 'input legitimacy'.

Various criticisms can be made of this notion of 'chain legitimacy'. One of them is its unhistorical and somewhat artificial, mechanical nature, which apparently ignores the sources of democratic legitimation that can derive from broad popular acceptance - or at least acceptance among those affected - of acts and measures to which one is subjected without having had an actual opportunity to influence those acts or measures ('output legitimacy'). It ignores the redeeming function of time and history. Yet, this alternative form of legitimacy is really only acceptable if there is some form of influence ('input') possible that could change those acts and measures in future, and undo or amend those acts, even if this input is not necessarily so neatly locked into the shackles of a chain linking an act to one actor or group of actors. This form of legitimacy relies on the dynamic potential inherent in history: politically there is no 'End of History' - history is not frozen into the decisions once taken, the laws once passed and the constitutions adopted once upon a time.

This brings us to another important criticism of the 'chain' approach. The links in the chain are not as strong as they seem: it is self-evident that the people - whatever

\footnotetext{
${ }^{10}$ The locus classicus in the German constitutional literature is Ernst-Wolfgang Böckenförde, 'Demokratie als Verfassungsprinzip' (\$24), in Josef Isensee and Paul Kirchhof (eds), Handbuch des Staatsrechts der Bundesrepublik Deutschland (CF Muller 2004) Bd. II, 3. Auflage.
} 
the 'people' might be if it is not to be identified with the electorate - is not necessarily the same as the electorate, nor is the electorate the same as the elected, nor the elected the same as the executive they appoint; nor is the will of the one the same as that of the other within this legitimacy chain. This is no doubt true, but it is not something we should disapprove of, as is exploited in oppositional rhetoric that reproaches the powers that be for being inherently alienated from those whom they should stand for. The criticism is unjustified that representational claims are problematic because of a lack of identity between the represented and the representatives. It is true that a democracy rests vitally on the idea of a certain proximity between the citizens and the electorate, between electorate and elected, as well as between the elected and their appointees to the citizens. ${ }^{11}$ And yet, a critical distance between the represented and representative is vital to democracy. Ultimately a full identity of the represented and the representative can be dangerous. Precisely the claim to exclusiveness and the coextensive identity between the represented and the representative, requires the elimination of the difference and necessary tension between the represented and the representative. Eliminating that difference amounts to eliminating contestation, controversy, and dissent, which are rightly said to be the essence of the 'political'; ${ }^{12}$ it is hence actually a threat to democracy.

In line with this, it is essential to democracy that societal actors are indispensable counterparts to the constitutional institutions. It would be pernicious to identify democracy with the state and its institutions. A democratic state can only exist if it lives by the awareness that civil society is a necessary precondition of political institutions.

\section{Counterbalances: Division of Powers}

Elections are a quintessential element without which no democracy can exist, but they do not sufficiently establish democracy in the sense of a political society in which citizens have influence on the government by which their daily lives are affected. Apart from the democratic preconditions of elections - free, fair and secret, based on freedom of expression, association, assembly etc. - in political orders as we know them, democracy is classically understood to require setting up a range of institutions that allow for counter-balances against concentrations of power institutions that we are well acquainted with under the names of separation, division and balance of powers, classically encapsulated in the metaphor of the trias politica. ${ }^{13}$

\footnotetext{
${ }^{11}$ For a fuller discussion, see Pierre Rosanvallon, La légitimité démocratique: impartialité, réflexivité, proximité (Editions du Seuil 2008) part IV, 'La légitimité de proximité'.

${ }^{12}$ A central point in the work of Chantal Mouffe.

${ }^{13}$ This convenient reduction to three political institutions is, of course, not a very precise representation of the sites of political power within the order of a democratic state; powers are
} 
Subjection of public authorities to law is naturally a starting point in this. And having independent courts to assess citizens' claims of the unlawfulness of certain acts, not only of other citizens but also of public authorities, is a core element of the quality of a democracy in Europe.

If it is the purpose of a division of powers in which courts have a role to play in contributing to the democratic quality of the polity, as we believe it is, there is nothing inherently undemocratic about judicial review of executive and legislative acts. Courts are there largely to uphold the rights of citizens, and it must be assumed that these have been democratically granted to them by the legislature. However much one may disagree with the outcomes of court cases or the reasoning on which they are based, given the role of courts, it undermines democracy - and not merely the rule of law - when the independence of courts is tampered with by the government of the day, as we see happening, for instance, in Hungary and Poland.

This is not to say that in a democratic Europe the powers of courts should be uniformly designed. There is not one model for the architecture and powers of courts as regards the review of legislative acts. There is not even a single model for the review of executive acts, a review that we have learnt to accept as a necessary part of judicial protection of citizens within any European democracy. And even though we lawyers may have a bias towards codification and uniformity, from a democratic point of view it is not commendable to impose one single model. A wise court is aware of its position within the trias politica, and the democratic merits of its own position and that of the legislature and the executive. Nevertheless, once there is a competent court to adjudicate claims, particularly claims against acts under public law, democracy - in this case, the power of citizens to have a legitimate influence on contested decisions by which they are affected, through the possibility of having their lawfulness reviewed - requires judicial independence. Claims that judges are 'so-called judges' (Trump), or that courts are 'fake courts' (Wilders) veil the suggestion that these judges and courts should be replaced by the true representatives of the true people, that is to say, those who would judge in favour of the 'powers that be' (or should be). This is not only putting an end to separation of powers, it would also herald the end of democracy, which must necessarily be an open democracy.

\section{The Democracy of the EU Institutions}

Now what about the democratic quality of the institutional make-up of the EU itself? Merely holding European elections is not enough to turn the EU institutions into a democracy, even though the democratic preconditions for such elections are fulfilled. The exercise of power of the EU is divided among a wide variety of

distributed among the bureaucracy, agencies, and certain authors have included also institutions of civil society such as the media, etc.; for an elaboration see e.g. Rosanvallon, supra n. 11. 
institutions, including the courts of the EU itself, while it has also worked hard at involving social actors in large sections of its work. This has been recognised by no less than the Bundesverfassungsgericht in its Lisbon judgment. It hailed the Union's search for new ways of rendering democracy complete (eigene Wege demokratischer Ergänzung) through 'novel forms of transparent and deliberatively designed political decision-making. ${ }^{14}$ It added that these cannot replace democratic elections - and of course they do not.

The last European Parliament elections reinforced the turn towards an increased political leverage of Parliament on the composition of the Commission in the image of the parliamentary systems of government as they have come about in the course of the $19^{\text {th }}$ and early $20^{\text {th }}$ centuries in the older Member States. Contrary to what the Treaty text suggests, ${ }^{15}$ and assuming that the practice surrounding Spitzenkandidaten established a constitutional convention, ${ }^{16}$ it is no longer within the European Council's discretion to propose who is to be the president of the Commission to the European Parliament, but the European Parliament itself determines this on the basis of the electoral results. It is ironic that just as this would seem to have increased the parliamentary democratic legitimacy of the Union institutions in traditional constitutional terms, Member State democracies threaten to turn away from the Union.

One element in this irony may be that national democracies and the system of government of the Union itself somehow do not sit together as comfortably as one might wish. The Pavlovian reaction in the European institutions, particularly among Commissioners, to criticise referenda that have or might have a negative outcome is one symptom of it. It is not that the institutions and their members could be understood to be against all referenda. No objections were raised against the referenda that made accession to the Union or Treaty amendments possible. The reality that the present shape of the EU is the result of referenda in a large majority of the Union's Member States, and depends on constitutional supermajorities in others, ${ }^{17}$ could even be mustered as evidence

${ }^{14}$ BVerfG 30 June 2009, 2 BvE 2/08, Lisbon, para. 272; the reference is to Art. 11 TEU. That these ways are considered to be novel gives pause for thought on the social quality that the Court associates with democracy within Member States.

${ }^{15}$ Art. 17(7), first sentence, TEU.

${ }^{16}$ Editorial, 'Between the Constitutional Document and the Constitutional Settlement', 10 EuConst (2014) p. 375 at p. 376-377. The Spitzenkandidaten practice has a certain parallel in the electoral practice in for instance Italy, where the designate prime minister has to be on the ballot paper, and in the Netherlands, where in practice parties by indicating their 'candidate prime minister' indicate who should be allowed to make the first attempt at forming a cabinet, a rule that in the 1960s was thought to require a constitutional amendment (that was not adopted at the time).

${ }^{17}$ For a detailed overview see L. Besselink, et al., National Constitutional Avenues for Further EU Integration, Study, European Parliament, Directorate General for Internal Policies, Policy Department C: Citizens' Rights And Constitutional Affairs, Legal Affairs Committee, Constitutional Affairs 
of its democratic legitimacy. ${ }^{18}$ The problem with this type of response to referendawhatever hesitations or objections one can legitimately have to referenda in the $\mathrm{EU}$ context ${ }^{19}$ or against constitutional supermajorities in general - is that democracy thus seems not to be cherished as a political value in itself but in a purely instrumental way as granting legitimacy to the powers that be. This is a problem that is not specific to the EU; those who are in power, and that includes parliamentary majorities as much as minorities, are prone to the temptation of instrumentalising democracy. It is a matter of democratic culture for those in power to be able to resist that temptation. The lack of a historically deeply-rooted democratic tradition of the EU institutions probably makes the challenge greater for them than for longerestablished democracies in Member States. But it is a challenge that must be taken seriously if democracy is to be taken seriously.

\section{Democratic Counterparts: Scrutinising EU and Member State Democracy}

The Member States themselves are democracies - such is the assumption. And this is precisely why some constitutional courts, the Bundesverfassungsgericht being among the more explicit ones on this, base certain forms of critical scrutiny of Union measures on the premise that the Union must be democratic, which encompasses assessing the limits of the attribution of powers to the EU institutions that Member State parliaments or citizens in referenda have democratically assented to. In this way and to this extent, there is a democratic justification for judicial scrutiny of EU law by Member States' courts, a democratic justification for acting as a counterbalance, a justification for meddling with the EU that is based on the assumption of the Member States' democratic quality.

Member States are democracies - such is the assumption. But what if that assumption becomes questionable? What if the quality of democracy in Member States is eroded? The question is a sequel to the logic of democratic consolidation through accession to the Union of Member States which had shed dictatorships, a logic that has applied ever since the accessions of Greece, Portugal and Spain to the Communities - a democratic consolidation that was part of the very motives for post-war European integration from its inception, as we already remarked. And it is inherent in the political nature of Union ever since the Maastricht Treaty.

Notwithstanding the declaratory tone of Article 2 TEU, this provision was not meant to remain toothless. We saw that already in Kadi (I): this provision

Committee, PE 493.046 EN, (March 2014), available at <www.europarl.europa.eu/RegData/etudes/ etudes/join/2014/493046/IPOL-JURI_ET\%282014\%29493046_EN.pdf>, visited 20 April 2017.

${ }^{18}$ See <english.eu.dk/en/faq/faq/referendums>, visited 20 April 2017.

${ }^{19}$ A. Auer, 'The people have spoken: Abide? A critical view of the EU's dramatic referendum (in) experience', 12(3) EuConst (2016) p. 397. 
(to be precise its predecessor Article 6(1) TEU) was pivotal for the European Court of Justice to conclude that no law can be effective, neither primary EU law nor even international law that prevails over primary EU norms, if that law infringes the fundamental principles on which the Union is based. ${ }^{20}$ Leaving aside for the moment the judicial enforceability of democracy as a value in Article 2 $\mathrm{TEU},{ }^{21}$ we have the political procedure of Article 7 TEU to enforce it and to sanction its infringement. In other words, the political entwinement of the Union and Member States carries with it a mutual interest in each other's democratic quality. The very commonality of this value should make the difference when it comes to the mutual political interest that Member States should have as between them, as compared with the interest that a third country, say Turkey, Russia or China, has in the democratic quality of any particular one of the Member States. ${ }^{22}$

This democratic quality of Member States must go beyond the issue of whether a parliament and government are based on free elections: it is also about the democratic conditions under which government operates and the space they leave for citizens to have some degree of influence. That is precisely what is explicitly rejected by the Hungarian prime minister, Orbán Viktor. His aim is to establish an 'illiberal democracy', a 'labour based State', after the models of Singapore, Russia, Turkey and China: 'The liberal social organizational principles and methods must be discontinued'. ${ }^{23}$ Unfortunately, this is not intended as an academic or conceptual discussion of liberalism, free market ideology, constitutionalism and democracy, but it has a highly practical, ominous meaning. In practice it has meant rolling out a programme of cracking down on the independent judiciary, the ombudsman, the data protection authority, civil society organisations, the media, freedom of expression and of religion, ${ }^{24}$ NGOs,

${ }^{20}$ ECJ 3 September 2008, C-402/05 P, Kadi, paras. 303-304: 'Those provisions cannot, however, be understood to authorise any derogation from the principles of liberty, democracy and respect for human rights and fundamental freedoms enshrined in Article 6(1) EU as a foundation of the Union. Article $307 \mathrm{EC}$ may in no circumstances permit any challenge to the principles that form part of the very foundations of the Community legal order, one of which is the protection of fundamental rights, including the review by the Community judicature of the lawfulness of Community measures as regards their consistency with those fundamental rights.'

${ }^{21}$ See L.F.M. Besselink, 'The Bite, the Bark and the Howl: Article 7 TEU and the Rule of Law Initiatives', in A. Jakab and D. Kochenov (eds.), The Enforcement of EU Law and Values: Ensuring Member States' Compliance (Oxford University Press 2017) p. 128.

${ }^{22}$ The EU and its Member States' particular interest in the democratic quality of Turkey resides in the latter's association with the EU since 1963 and its official status as a candidate Member State since 1987.

${ }^{23} \mathrm{See}$ <www.kormany.hu/hu/a-miniszterelnok/hirek/a-munkaalapu-allam-korszaka-kovetkezik>, visited 20 April 2017: 'A liberális társadalomszervezési elvekkel, módszerekkel szakítani kell'.

${ }^{24}$ For an overview, see for instance Hungary: Democracy under Threat (Fédération internationale des ligues des droits de l'Homme, November 2016). 
particularly foreign ones, and most recently foreign universities that take academic freedom and open debate a bit more seriously than the regime likes, such as the Central European University. ${ }^{25}$

\section{The Impotence of the EU Institutions and Member States}

The European Commission hesitantly began quite impotent infringement proceedings, on grounds of age discrimination of judges, supplemented later with one on asylum legislation; the EU Member States remained quiet. Poland's present government is of the same kind as the Hungarian one, and is rolling out a similar programme to dismantle democracy, striking first at the independence of the Constitutional Court and now also at that of the president of its Supreme Court, and more broadly the National Council for the Judiciary, so as to influence any judicial appointment. ${ }^{26}$ Its attack on free media is well documented. Again, the other EU Member States remain silent. The European Commission this time seemed more alert, developing in the aftermath of the, by then, lost cause of Hungary's democracy a 'rule of law' monitoring mechanism. Yet again it did not deliver. The Commission got as far as issuing a 'rule of law opinion', followed by a 'rule of law recommendation' in July 2016 (supplemented in December), setting out that it considers that there is a systematic threat to the rule of law in Poland. And after some secret diplomatic correspondence it has basically stopped there. The official explanation is that the Commission fears not having sufficient support in the Council ${ }^{27}$ - which may be true, even though the Visegrád countries at the moment do not form a blocking minority that stands in the way of determining by a qualified majority that 'there is a clear risk of a serious breach by a Member State

\footnotetext{
${ }^{25}$ Government paper nr T/14686 CCIV bill amending the national higher education Act of 2011, <www.parlament.hu/irom40/14686/14686.pdf>, adopted on 4 April 2017 with 123 against 38 votes; for a negative response of the US Department of State, see <www.state.gov/r/pa/prs/ ps/2017/03/269343.htm\#.WN5L8Lh0hL0.twitter>, visited 20 April 2017; for a discussion at the press conference of CEU rector Michail Ignatieff, see <youtu.be/0XIkvfu2inc>, visited 20 April 2017.

${ }^{26}$ For an analysis see Piotr Mikuli, 'An Explicit Constitutional Change by Means of an Ordinary Statute? On a Bill Concerning the Reform of the National Council of the Judiciary in Poland', VerfassungsBlog, 23 February 2017, <verfassungsblog.de/an-explicit-constitutional-change-bymeans-of-an-ordinary-statute-on-a-bill-concerning-the-reform-of-the-national-council-of-the-judiciaryin-poland/>; for a comparative perspective see A. Sanders and L. von Danwitz, 'The Polish Judiciary Reform: Problematic under European standards and a Challenge for Germany', VerfassungsBlog, 28 March 2017, <verfassungsblog.de/the-polish-judiciary-reform-problematic-under-europeanstandards-and-a-challenge-for-germany/>, visited 20 April 2017.

${ }^{27}$ Declaration Commission vice-president Timmermans in a hearing of the LIBE Committee of the EP, <www.europarl.europa.eu/ep-live/en/committees/video?event=20170322-1500-COMMITTEE-LIBE>, visited 20 April 2017.
} 
of the values referred to in Article 2'. ${ }^{28}$ Apparently, there are more Council members blocking the adoption. The European Parliament has the power of initiative here as well as the Commission (or a third of the Members of the Council), but, as is not unusual, it makes a fuss but fails to act or take the initiative itself. $^{29}$ So much for the militancy of EU democracy.

\section{Democratic Militancy as Nuclear Option}

There are several ways in which the inadequacy of Europe's answer to political threats to democracy can be understood. One way of approaching this is by looking at one of the greatest blunders at the basis of the present strategic failure of the institutions. That was Barroso's characterisation of the sanctions procedure under Article $7 \mathrm{TEU}$ as 'the nuclear option': ${ }^{30}$ its invocation is claimed to destroy the Union. Far from the somewhat free use of a metaphor, this expression has become standing Commission policy, permeating Commission documents and statements. ${ }^{31}$

This is a gross mistake. Firstly, this qualification simply ignores the content, nature and intention of Article 7 TEU. Its first paragraph is merely about monitoring situations in which there is clear risk for a serious breach of the democratic principle and the other founding values of the Union and the Member States. Is the Union such a shaky constellation that using this is really blowing it up? Indeed, the failure to take the situation in Hungary and Poland seriously may have actually led to the existence of a serious and persistent breach of the values referred to in Article 2 TEU. Taking further steps, including sanctions by qualified majority, requires a unanimous assessment by the European Council (without the

\footnotetext{
${ }^{28}$ Art. 7(1) TEU: 'On a reasoned proposal by one third of the Member States, by the European Parliament or by the European Commission, the Council, acting by a majority of four fifths of its members after obtaining the consent of the European Parliament, may determine that there is a clear risk of a serious breach by a Member State of the values referred to in Article 2. Before making such a determination, the Council shall hear the Member State in question and may address recommendations to it, acting in accordance with the same procedure'.

${ }^{29}$ Yet another well-intended institutional proposal that further distracts from the procedures provided for in the TEU is the European Parliament's proposal for an inter-institutional agreement: European Union Pact on Democracy, the Rule of Law and Fundamental Rights, A8-20160283_EN-1.

${ }^{30}$ State of the Union Address 2012, <europa.eu/rapid/press-release_SPEECH-12-596_en.htm>, repeated in the State of the Union Address 2013, <europa.eu/rapid/pressrelease_SPEECH-13-684_ en.htm>, visited 20 April 2017.

${ }^{31}$ E.g. Viviane Reding, Vice-President of the European Commission, Safeguarding the rule of law and solving the 'Copenhagen dilemma': Towards a new EU-mechanism (General Affairs Council/ Luxembourg, 22 April 2013); Communication from the Commission to the European Parliament and the Council, Brussels, 11.3.2014 $\operatorname{COM}(2014) 158$ final, p. 2.
} 
vote of the countries concerned) that this is the case. It takes courage to do so. But the unanimity requirement means necessarily that this is not blowing up the Union, but keeping the Union together faced with an attack on its very foundations.

Secondly, saying that any use of Article 7 TEU is reverting to a 'nuclear option' must have been a great reassurance to the Orbáns and Kaczyńskis of Europe: it means that it would never ever be triggered by the Commission. The Commission kept its word and so did Orbán and Kaczyński. Talking about Article 7 TEU as a nuclear option comes at the expense of destroying the Union's democratic foundation. Tremendous harm has been done in the meantime, but let us see whether the Juncker Commission can do better. ${ }^{32}$

\section{Democracy - European Democracy}

The Commission has so far narrowed down the values of Article 2 to the 'rule of law', thus wiping under the carpet the political nature of the Union and instead focusing on the instrumental part of constitutional democracy, the rule of law, at the risk of setting it up against democracy. Of course, there are conceptions of the rule of law that imply democracy. Yet it is quite clear that this cannot be taken for granted, as is demonstrated by Orbán's much admired examples of Singapore, Russia, Turkey and China: also authoritarianism can be based on a certain conception of the rule of law, and the Polish government plays the card of formal legality to the full against a mute Commission. In fact, in its document on the Rule of Law Monitoring mechanism, the Commission cannot come up with anything better than justifying this monitoring by reference to the mutual trust that is necessary for the Union to function adequately. No doubt trust is functionally necessary, but is such an essentially instrumentalist approach an appropriate or sufficient basis for the political identity of the Union? Mutuality is a precondition for the operation and existence of any polity, also a feudal one. ${ }^{33}$ The rule of law is pretty empty if it is merely understood instrumentally as guaranteeing the mutuality that underpins the internal market. So thin a notion of the rule of law could even underpin authoritarian and autocratic claims to be the true representative of the people. But that is not what we could understand an 'area of freedom, security and justice without internal frontiers' constituting a European polity to mean.

So it might be a step forward to talk about democracy, European democracy. Of course, it is based on elections, referenda, and majority decision-making, but

\footnotetext{
${ }^{32}$ The Vice-President in charge, Timmermans seems more careful, but one may wonder whether it is helpful to call its invocation 'self-defeating', Timmermans, supra n. 3 at 1:00:45.

${ }^{33}$ Fides was central to the status of subjected peoples in the Roman empire, and was the basis of feudal society in the Middle Ages.
} 
cannot be reduced to that. It must encapsulate a full institutional set-up for wielding power to prevent despotism, including an independent judiciary and the preconditions of liberty in a civil society that exerts influence on the way in which power is wielded - a democracy that is open to society, open to debate and fundamental disagreement. That is the European democracy we should talk about. A failure to do so threatens European democracy.

LB, JHR 